\title{
高重复频率激光等离子体软 $\mathbf{X}$ 射线光刻实验*
}

\author{
郭玉樹 \\ (中国科学院长春邮电学院五系, 长春 130012)
}

\section{关链词激光等离子体 软 $\mathrm{X}$ 射线 光刻 抗蚀剂}

高重复频率激光等离子体软 $\mathrm{X}$ 射线光刻术是国际上制作亚微米及深亚微米量级微器件、 微结构的关键技术方法之一 ${ }^{[1,2]}$. 目前国内尚未见有关报道.

本文建立的激光等离子体软 $\mathrm{X}$ 射线曝光实验装置 (图 1) 主要由软 $\mathrm{X}$ 射线源和曝光室组 成. 软 $X$ 射线激励源为脉冲重复频率 $10 \mathrm{~Hz}$ 的 Continuum 9010 型调 $Q$ 的 Nd: YAG 激光器. 其脉冲能量为 $2 \mathrm{~J}$, 脉冲宽度 $8 \mathrm{~ns}$, 激光束发散角 为 $0.45 \mathrm{mrad}$. 采用 $f=100 \mathrm{~mm}$ 的非球面透镜, 将 $1.06 \mu \mathrm{m}$ 激光束经靶室的绝热玻璃入窗聚焦 到圆柱靶面上. 实测靶面径向跳动小于 $40 \mu \mathrm{m}$. 用步进电机驱动靶绕其轴均匀旋转同时沿轴向 移动, 可编程控制器对步进电机的步长、步频作 实时控制, 以保证每束激光脉冲打到新鲜的靶面 上. 激光聚焦后的焦斑尺寸约为 $150 \mu \mathrm{m}$, 靶面 激光功率密度不低于 $1.1 \times 10^{12} \mathrm{~W} / \mathrm{cm}^{2}$, 曝光装 置内的气压低于 $2.7 \times 10^{-3} \mathrm{~Pa}$.

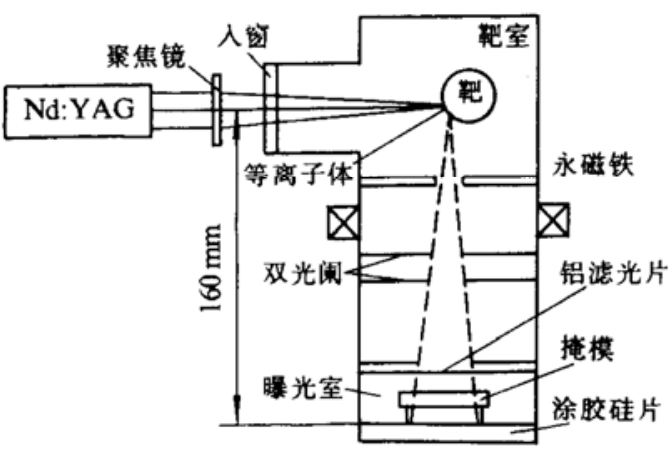

图 1 激光等离子体软 X 射线 曝光装置示意图

在激光靶室和曝光室间增设孔径 $\emptyset 10 \mathrm{~mm}$ 的双光阑, 并加装一对表面磁感应强度 $0.2 \mathrm{~T}$ 的钐钴合金永磁铁, 可缓解等离子体带电微粒和 金属蒸气的溅射作用. 综合考虑光强和溅射对曝光结果的影响, 经实验确定光源与硅片表面 的距离为 $160 \mathrm{~mm}$. 在掩模前加装了带聚丙稀膜衬底的铝滤光片, 其中聚丙稀膜厚 $1 \mu \mathrm{m}$, 蒸镀 铝厚 $200 \mathrm{~nm}^{[3]}$. 可滤除 $5 \mathrm{~nm}$ 以上的长波长辐射, 避免由于长波长光衍射导致的光刻分辨率 下降.

掩模吸收体分别是 $50 \mathrm{l} / \mathrm{mm}$ 的自支撑网丝和 $1200 \mathrm{l} / \mathrm{mm}$ 带聚酰亚胺衬底的软 X 射线透 射光棚. 金栅线厚度 $\geqslant 0.5 \mu \mathrm{m}$, 线空比约为 $1: 1$. 采用 $1: 1$ 接近式曝光方法. 将正性抗蚀剂 PMMA 在 $150^{\circ} \mathrm{C}$ 下预烘 $60 \mathrm{~min}$. 每次曝光前, 将自支撑网丝或透射光栅置于涂胶硅片前约 20 $\mu \mathrm{m}$ 处, 为了保证在小间隙条件下使掩模和硅片能精密对准, 在光电显微镜下采用具有双重焦 点光学系统的十字丝自动位置对准方法, 将掩模和硅片安装在卡盒内放入曝光室. 由 $\mathrm{Pb}$ 靶

1995-08-28 收稿, 1996-03-28 收修改稿

* 应用光学国家重点实验室基金资助项目 
发射的 X 射线持续曝光 $30 \sim 60 \mathrm{~min}$, 然后在 MIBK 和 IPA 的混合液中显影, 比例一般为 $2: 1$, 显影时间为 $0.5 \sim 5 \mathrm{~min}$, 最后在甲醇溶液中清洗.

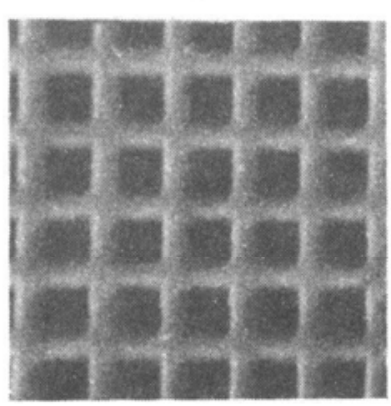

图 $250 \mathrm{l} / \mathrm{mm}$ 自支撑网丝的 SEM 光刻显微图形

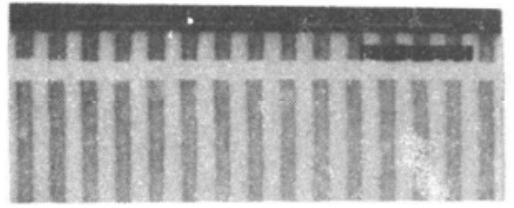

图 3 线宽 $0.4 \mu \mathrm{m}$ 透射光栅的 SEM 光刻显微图形

图 2 是以 $500 \times$ 拍摄的自支撑网丝的 SEM 光刻显微照片. 图 3 是以 $8750 \times$ 拍摄的对应 于透射光栅的 SEM 光刻图形. 透射光栅的等间距刻线宽度 $0.8 \mu \mathrm{m}$, 其间的金栅线宽为 0.4 $\mu \mathrm{m}$. 故本实验初步得到的最小刻线宽度为 $0.4 \mu \mathrm{m}$, 证实了高重复频率激光等离子体软 X 射 线源在微细加工技术研究中所具有的实用性和潜在优势.

\section{参考 文献}

1 Hoffman A L, Albrecht G F, Crawford E A et al. High brightness laser plasma source for high throughput sub-micron X-ray lithography. Proc SPIE, 1985, 537:198 205

2 Toubhans I, Fabbro R, Gauthier J C et al. X-ray conversion efficiency in laser-produced plasmas. Application to X-ray lithography. Proc SPIE, 1989, $1140: 358 \sim 364$

3 李惁廉, 申明阳, 邵桂英等. 软 X 光滤光片的研制. 光学学报, 1986, 6(6): 493 499 